\title{
Fairies Wear Thongs
}

\section{Ben Iser}

I WAKE UP on the hard bunk bed of the local lock-up. I grunt and stand up. I'm fuckin' filthy and me feet are all cut up and blistered, and I'm naked. I look out the window into the cop-shop's yard and see a burntout Falcon. It takes a few minutes before I realise it's mine. Everything I own was in that car. I'm lookin' at it wonderin' why it's here and how it got so fucked up when I hear a voice behind me.

'So you're conscious at last, eh?' It's the Senior Constable. Me feet hurt like fuck as I walk over to the door. It's unlocked.

'Any chance of a drink?' I ask. 'Me throat's dry as a nun. What the fuck happened?'

'Last night you stumbled into town,' Bill replies, 'totally off your tits, wearing a dirty nappy, and raving about some 'little Scottish cunt'. You passed out in the street. What the fuck have you been doin'?'

'It was only yesterdee mornin' . . .' I say.

Me fave mix-tape is about halfway through the Sabbath song Fairies Wear Boots when the Falcon gives an enormous shudder and dies. I lean back in my seat and roll a gasper. When it comes to spending me last lobster on a drink for the car or a pouch and papers, weeeell-I stand by me choice. I guess there weren't enough juice in the tank after all, so I should say walk by me choice. If the plain wrapped Pig hadn't been at the servo, I woulda just filled me tank and fucked off like I usually do.

Finishin' me rollie, I get out of the car and walk around to the boot. I lift the lid and dig around in the empty beer cans, ciggie packs, 
food wrappers and other shit. How the fuck does this crap gets from inside the car to the boot? I'm lookin' for the jerrycan that was in here when me Old Man gimme the car for me twennyfirst. Finally, I find it. Empty. The large rusty hole in the bottom prob'ly has somethin' to do with it. I hurl the can, hard. It makes a satisfying clang as it lands further up the road.

I take out me tobacco pouch and roll another. I try to figure out where I am. I'm on McGulloughs Road, not far from the old timber mill on the Six Mile Creek. Some people reckon these hills are haunted but they're full of shit. I used to go huntin' out here with the Old Man when I was a little tacker. Ya know that gettin' to town by road ya gotta 'round the end of the hills. It's about twenny clicks in a fuckin' big u-ey. But it's fuck-all distance if ya go as the crows fly. I reckon if I follow the creek up into the hills, I should get over the ridge, cut through the pine plantation, and get into town just near the Albion. A bit of a walk, but there's a pub at the end.

Fuck-all people come out here nowadays so it'll be better than sittin' on me arse hopin' for a lift. Shit, I could be sittin' here for a week.

I look in the car for some supplies. I got me pouch, four tinnies and some barbecue chips. I find a pair of mouldy old runners and change into 'em. Even I'm not dumb enough to go bush wearin' thongs. I shove all me stuff into a placcy carry bag, tie a flannie 'round me waist and set off.

I leave the car and push through the tall, dry, summer grass at the side of the road. Climbin' through the barbwire into the paddock between me car and the old mill, I can tell it's a cow paddock by the lack of grass and all the dust. The last decent rain around here was a year ago. Fucking cows. I've been workin' the muster up North, rounding the fuckers up so some bastard can turn 'em into burgers.

I wander along, half asleep in the hot sun, thinkin' back on the last couple-a years. I've never learnt to keep me hands to meself. Me last stretch inside was for shopliftin' in a bottle-o. Since getting out I been driftin' up and down the back roads, followin' the seasons: shearin', pickin' fruit, just takin' whatever earner come my way an tryin' to avoid trouble.

I'm not far from the mill when I hear a thumpin' sound behind me. I look over me shoulder and see a fuckin' big bull chargin' right at me. I run like fuck for the fence. I'm fucking fast on me feet. The only thing I liked in school was athletics. I can hear the big bastard pantin' behind 
me as I sprint like fuck. When I reach the fence, I jump the wire. The bull pulls up just short of the fence and bellows.

'Ha! Fuck you ya big cunt!' I shout at him.

I get up and feel air on me sack. Me jeans've torn from arse to balls and the guts've come outta me carry bag. All I've got left is one tinnie. All the rest of me swag is in the paddock. Fucked if I'm goin' back for it. Fortunately I'd stuck me pouch in me jeans pocket so I can still have a smoke. I light up and crack open the tinnie. It's warm and shaken, so half the can froths over me hand. I skull the can, slurpin' up as much beer as I can. Me gut's still growlin' as I finish and I wish I had a Four'n'Twenny or somethin'.

I walk along the steep creek banks, lookin' for a spot where I can cross. I pass by the old mill and its pond, up to some old pylons that used to support a small bridge. The bridge washed out yonks ago but there's enough of it left to snag a big log. Other branches and crap have caught by the log making a floating platform across the fast flowing creek. I'm nearly across when the fucker shifts under me and I'm tipped into the cold water. The creek is only four foot deep but the current is strong enough to wash me downstream before I can stand. I'm swept over a fall into the mill pond. I swim to the bank and pull meself out of the cold water. At least I've cooled off. Nothin' like a swim to take the edge off the summer heat.

I take off me jeans to let 'em dry faster and I tie me flannie up and under into some makeshift shorts. That's when I see a large ring of mushrooms. I fuckin' love mushies and so even though I've got nothin' to cook 'em on, I'm so fuckin' hungry I go at 'em.

After me feast I go to roll a gasper and realise that me tobacco is soaked through and me papers are completely fucked. I stand there swearing about me crap luck when a squeaky voice asks 'Whit's wrong laddie?'

I turn around and there's a fuckin' goat-man standin' by some rocks. I look at him, gobsmacked. His clothes are normal enough, footy shorts and a Demons jumper. But he has horns on his head and his arse and legs are those of a goat: fuckin' hairy backward knees, cloven hooves; the fuckin' lot. 'Who ...' I stare some more, 'WHAT the fuck are you?'

'I'm an Urisk,' the ugly little bastard replies, 'a fairy bound to the mortal plane. Connell is ma name an' McCullough is ma clan. Ye seem tae have a wee problem.' 
I show him me soggy tobacco and papers. He nods, pulls out a small knife, picks up a large gumnut and with movements too fast to see carves a pipe bowl. Fitting a length of dock-weed for a stem, he hands it to me along with a small leather pouch. There's some sort of green shit in the pouch but, fuck it, a smoke is a smoke.

He motions me to follow him. Having no better options, I grab me jeans and walk after him into the hills.

'Where ya from?' I ask, 'Ya sound Scottish.'

'Aye, I am.' He tells me how he followed a mate out to Oz during something called The Clearances. He owed a debt of honour or some bullshit. He talked for ages about the Highlands. He's enjoying the sound of his own voice, and by the time he's finished we're well into the hills. He leads me to a little cave on top of the ridge above the pine plantation north of town.

He takes a seat on a rock and motions me to do the same. It's gettin' close to dusk. He goes to a small barrel and pours somethin' into two wooden cups. He hands me one and I give it a sniff. It smells like beer. I take a drink. It is beer!

I'm full of questions for the little bastard. 'So if ya come out 'ere in the eighteen fuckin' forties, how old are ya? Ya don't look too fuckin' old. And if you've been out here for so long how come none of us has seen ya? And if you've been fuckin' hidin', why show y'self now?'

'Time is experienced differently by ma people,' The Urisk says, 'normally ye cannae see $\mathrm{u}$ 'cause ye nae believe in us, but then ye ate my mushrooms. By eatin' a fairies' food ye crossed into my world, y'ken?'

I sit down and make meself comfortable, 'If you're a fairy, how come ya not wearin' boots?'

'Whae ye talking aboot? I wear fookin' thongs.' I look at his feet, no- - his hooves, and sure enough, there's a strap comin' up and over the cleft of his hoof. He's wearin' a pair of tiny thongs. He picks up a wooden bowl and walks to the entrance of the cave. 'I'll gae 'n' get us somethin' else tae eat.'

As the Urisk trots off old habits kick in and I check out his little cave lookin' for anything of interest. I grab the barrel of beer, some odds and ends, and, under a pile of rags, I find a small golden flute. I'm makin' a swag outta me shoelaces and what's left of me jeans, I hear a strangled cry behind me.

'Whi' t'fook! Come 'ere y' coont!' 
I grab the shit and take off, but after a coupla steps me left shoe come off. I pause to grab it and that's when I see the Urisk. His whole fuckin' body is red with anger and he's produced a sharp lookin' knife from fuck knows where.

'I give ye aid and ye fookin' steal from me!' he shouts. The little fucker is so angry I can barely understand a fuckin' word he's sayin'.'I'll get even wi' you, I'll destroy everything you own, y'greet bastard!' He shouts after me. I forget about me shoe and just fuckin' bolt.

Runnin' down the hill, I trip on some rocks, drop me swag and me other shoe comes off. I try to scramble to me feet but the slope is really steep now and the pine needles are slippery. I can't get back up the hill to the rocks. Again, I hear the voice of the Urisk and I give up trying to get the shit back. I've still got the barrel so I head into town. I reckon it's just before midnight.

'You've been missing for fucking ages. Two months ago we responded to a big grass fire over on McCulloughs Road and found your car a burnt out wreck. Found your wallet and a bunch of other shit in Johnson's bull paddock and we've been looking for your carcass ever since.'

I remember what the Urisk said about time and destroying everything. Fucking bastard. 